Article

\title{
Adjustment and Optimization of the Cropping Systems under Water Constraint
}

\author{
Pingli An ${ }^{1, *}$, Wei Ren ${ }^{2}$, Xilin Liu ${ }^{1}$, Mengmei Song ${ }^{1}$ and Xuemin Li $^{1}$ \\ 1 College of Resources and Environmental Sciences, China Agricultural University, Beijing 100193, China; \\ liuxilin1989@126.com (X.L.); songmengmei@126.com (M.S.); lixm@apft.com.cn (X.L.) \\ 2 Department of Plant \& Soil Sciences, College of Agriculture, Food and Environment, University of Kentucky, \\ Lexington, KY 40506, USA; wei.ren@uky.edu \\ * Correspondence: anpl@cau.edu.cn; Tel.: +86-10-6273-3752
}

Academic Editor: Vincenzo Torretta

Received: 7 October 2016; Accepted: 17 November 2016; Published: 25 November 2016

\begin{abstract}
The water constraint on agricultural production receives growing concern with the increasingly sharp contradiction between demand and supply of water resources. How to mitigate and adapt to potential water constraint is one of the key issues for ensuring food security and achieving sustainable agriculture in the context of climate change. It has been suggested that adjustment and optimization of cropping systems could be an effective measure to improve water management and ensure food security. However, a knowledge gap still exists in how to quantify potential water constraint and how to select appropriate cropping systems. Here, we proposed a concept of water constraint risk and developed an approach for the evaluation of the water constraint risks for agricultural production by performing a case study in Daxing District, Beijing, China. The results show that, over the whole growth period, the order of the water constraint risks of crops from high to low was wheat, rice, broomcorn, foxtail millet, summer soybean, summer peanut, spring corn, and summer corn, and the order of the water constraint risks of the cropping systems from high to low was winter wheat-summer grain crops, rice, broomcorn, foxtail millet, and spring corn. Our results are consistent with the actual evolving process of cropping system. This indicates that our proposed method is practicable to adjust and optimize the cropping systems to mitigate and adapt to potential water risks. This study provides an insight into the adjustment and optimization of cropping systems under resource constraints.
\end{abstract}

Keywords: adjustment and optimization method; cropping systems; water constraint; water constraint risk

\section{Introduction}

"Cropping system" refers to the crops, crop sequences, and management techniques used on a particular field over a period of years, and is determined by the regional natural environment and social-economic conditions [1]. The evolving process of the cropping system to some degree reflects the utilization degree and its changing process of agricultural resources by humans. In recent decades, with the rapid growth in population and economic development, the demand for food production has been increasing, and accordingly, the demand for resources (such as land, water, and so on) for food production has also been increasing. Among all of the resources for food production, water has attracted global attention due to its increasing scarcity [2-7]. Water resource has become a critical bottleneck restricting food production in many countries and regions, especially in Northern China. People should adjust and optimize the cropping systems reasonably based on water resources to guarantee sustainable agricultural development. 
In Northern China, excessive agricultural irrigation for increasing the crop yields has seriously threatened the regional ecological safety. Under limited irrigation, high precipitation variations would bring high risk to the agricultural production. So, it is urgent to adapt agricultural production to these situations to supply enough food sustainably. The same issues have been met in other regions or countries. With the increasingly sharp contradiction between the demand for and supply of water resources, the water constraint to food production is increasing in many countries and regions in the world. In face of this situation, a large number of water saving techniques-such as pipe irrigation, drip irrigation, film mulching, and so on-have been applied to agricultural production. Though these techniques have greatly improved the water use rate and water use efficiency, excessive water uses have induced serious ecological degradation due to unchanged high water consumption of the crops [8]. Thus, the rational arrangement of agricultural production based on the supporting capacity of water resource is very urgent to promote regional sustainable development. To do so, recently, many active measures have been suggested, such as changing crop varieties based on the crop water demands $[9,10]$, adjusting the agricultural structure by growing crops with less water consumption and higher economic benefit (making it consistent with regional resource characteristics) [11-14], and so on. All these studies have recognized the seriousness of the water constraint to the agricultural sustainable development and the importance of the reasonable use of the limited water resource, while studies about how to adapt agriculture to the water-constrained situation are rare. With the accelerated deterioration of the water shortage situation, producing more food to satisfy the growing world population poses an unprecedented challenge to human ingenuity.

It has been suggested that the adjustment and optimization of cropping systems could be an effective measure to improve water management and ensure food security. However, a knowledge gap still exists in how to quantify potential water constraints and how to select appropriate cropping systems. With the increasing water scarcity today, there is an urgent need to explore the measures to adjust and optimize cropping systems to mitigate and adapt to potential water constraint risk to ensure food security and achieve sustainable agriculture. Here, we proposed the concept of water constraint risk, and developed a method for the evaluation of water constraint risk and adjusting/optimizing cropping systems by performing a case study in Daxing District of Beijing, China. Our results would be helpful for the adjustment and optimization of cropping systems to ensure regional agricultural sustainability.

\section{Study Area}

In this study, we chose Daxing $\left(116^{\circ} 13^{\prime}-116^{\circ} 43^{\prime} \mathrm{E}, 39^{\circ} 26^{\prime}-39^{\circ} 51^{\prime} \mathrm{N}\right)$ (Figure 1) located in the south of Beijing, China, a typical district for the dependent-on-water cropping system to conduct a case study. The annual average temperature is $11.6^{\circ} \mathrm{C}$, and the annual average rainfall is approximately $556 \mathrm{~mm}$. In 2011, the planted area of crops was $64,500 \mathrm{hm}^{2}$. During the recent 30 years, there were double cropping systems and single cropping systems. The double cropping systems mainly included winter wheat-summer corn, winter wheat-summer peanut, winter wheat-summer soybean, and so on. The single cropping systems included rice, spring corn, spring peanut, foxtail millet, and so on.

Since 1980, the evolving process of the cropping system in Daxing can be divided into three stages (Table 1). The first was from 1980 to the middle of the 1980s. During this stage, flat cropping and intercropping were the main planting patterns. In 1980, the total grain planted area was $68,667 \mathrm{hm}^{2}$, and rice, wheat, and corn area accounted for $31.14 \%, 34.27 \%$, and $21.26 \%$, respectively. In 1985, the total grain planted area was $64,600 \mathrm{hm}^{2}$, of which rice, wheat, and corn areas accounted for $15.07 \%, 40.04 \%$, and $35.19 \%$, respectively. During this period, the rice planted area began to shrink as water resources decreased. Accordingly, the wheat and corn planted area increased gradually, and the flat cropping system of winter wheat and summer corn expanded. The second stage was from the late 1980s to the 1990s. During this stage, the flat cropping system of winter wheat and summer corn developed greatly with the improvement of agricultural production conditions, reaching more than $60 \%$ of the total planted area. The other cropping systems included the flat planting of winter wheat and summer 
peanut, winter wheat and summer soybean, and so on. During this period, the planted area of winter wheat-summer grain accounted for about $75 \%$ of the total planted area. The third stage was after 2000. During this stage, the double cropping systems were gradually changed into single cropping systems because of increased water resource shortages. The winter wheat planted area showed a declining trend, while the spring corn gradually expanded.

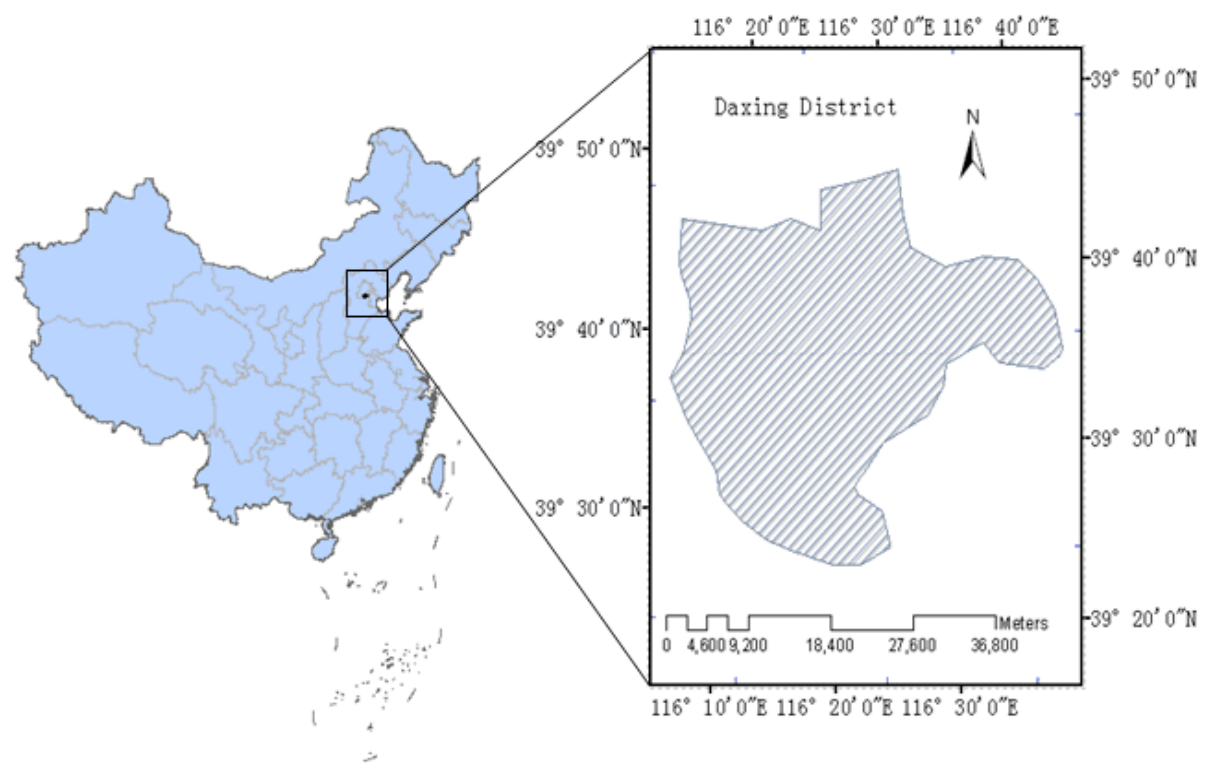

Figure 1. The case study region.

Table 1. The evolving process of the cropping system in Daxing since 1980.

\begin{tabular}{|c|c|c|c|c|}
\hline Time & $\begin{array}{l}\text { Typical Cropping } \\
\text { System }\end{array}$ & Staple Crops & Area Proportion & Planting Pattern \\
\hline \multirow{4}{*}{ Early to mid-1980s } & \multirow{3}{*}{$\begin{array}{l}\text { Winter wheat-summer } \\
\text { grain crops }\end{array}$} & $\begin{array}{l}\text { Winter wheat-summer } \\
\text { corn }\end{array}$ & $27.8 \%$ & \multirow{4}{*}{$\begin{array}{l}\text { Coexistence of flat } \\
\text { cropping and } \\
\text { intercropping }\end{array}$} \\
\hline & & $\begin{array}{l}\text { Winter wheat-summer } \\
\text { peanut }\end{array}$ & $5.5 \%$ & \\
\hline & & $\begin{array}{l}\text { Winter wheat-summer } \\
\text { soybean }\end{array}$ & $3.1 \%$ & \\
\hline & Single cropping of rice & Rice & $18.2 \%$ & \\
\hline \multirow{3}{*}{ Late 1980 s to $1990 \mathrm{~s}$} & \multirow{3}{*}{$\begin{array}{l}\text { Winter wheat-summer } \\
\text { grain crops }\end{array}$} & $\begin{array}{l}\text { Winter wheat-summer } \\
\text { corn }\end{array}$ & $46.6 \%$ & \multirow{3}{*}{ Main flat cropping } \\
\hline & & $\begin{array}{l}\text { Winter wheat-summer } \\
\text { peanut }\end{array}$ & $10.0 \%$ & \\
\hline & & $\begin{array}{l}\text { Winter wheat-summer } \\
\text { soybean }\end{array}$ & $6.1 \%$ & \\
\hline \multirow{4}{*}{ After 2000} & \multirow{3}{*}{$\begin{array}{l}\text { Winter wheat-summer } \\
\text { grain crops }\end{array}$} & $\begin{array}{l}\text { Winter wheat-summer } \\
\text { corn }\end{array}$ & $28.4 \%$ & \multirow{3}{*}{ Main flat cropping } \\
\hline & & $\begin{array}{l}\text { Winter wheat-summer } \\
\text { peanut }\end{array}$ & $8.5 \%$ & \\
\hline & & $\begin{array}{l}\text { Winter wheat-summer } \\
\text { soybean }\end{array}$ & $1.5 \%$ & \\
\hline & $\begin{array}{l}\text { Single cropping of } \\
\text { spring corn }\end{array}$ & Spring corn & $26.6 \%$ & \\
\hline
\end{tabular}




\section{Data and Methods}

\subsection{Data}

The daily meteorological data in Daxing from 1980 to 2010 were obtained from the Daxing meteorological observation station. The historical agricultural production data, including the regional crops' yields and crops' planted areas from 1980 to 2010 were obtained from the local agricultural administration department.

\subsection{Water Constraint Risk of Cropping Systems}

It is assumed that water constraint refers to that the amount of water does not meet the requirement for a system's development and restrains the development of this system at present or in the future. Generally, it performs in two forms-one is the water supply shortage in the short term, and the other is the potential constraint for the long-term development. At present, it is commonly accepted that the water constraint is determined by the scarcity of water; namely, the quantity or quality of the water supply cannot meet the demand, and thus it will restrain the development of a system.

The risk is the likelihood and magnitude of the loss occurred for the independent events [15-19]. When the supply of water is limited, the risk of production would occur. So, we suggest that water constraint risk refers to the constraint degree of water and magnitude of decrease in productivity due to the relative reduction of water for a specific product.

Accordingly, we define water constraint risk of a cropping system as the constraint degree of water multiplied by magnitude of decrease in the agricultural productivity due to the relative reduction of water for the cropping system. Under the water resources constraints, the agricultural productivity cannot reach the desired level, which may result in a decrease in resource water use efficiency, yield loss, and even the adjustment of the cropping system. The bigger the gap between the current water supply and the optimum water supply, the greater the constraint degree.

Water resources for agricultural production mainly include precipitation and irrigation water. Precipitation is the only water source for agriculture in the rain-fed agricultural regions. The reduction of water resources during the entire growing season or some key growth periods would induce the risk of cropping systems, i.e., the crop growth and development may be restricted.

\subsection{Calculation of the Water Constraint Risk}

As defined above, the water constraint risk of a cropping system is the product of the constraint degree of water and the magnitude of decrease in yield due to a reduction in the water supply. Accordingly, the water constraint risk of crop $i$ during a certain period (e.g., a month or a specific growth period) or during the whole growth period can be calculated by using Formula (1).

$$
F_{i}=R_{i} \times C_{i}
$$

where $F_{i}$ is the water constraint risk of crop $i$ in $\mathrm{kg} / \mathrm{hm}^{2}, R_{i}$ is the constraint degree of water supply of crop $i$, and $C_{i}$ is the yield loss of crop $i$ in $\mathrm{kg} / \mathrm{hm}^{2}$ during a certain or the whole growth period.

$R_{i}$ can be computed as Formula (2).

$$
R_{i}=1-\alpha_{i}
$$

where $\alpha_{i}$ is the coupling degree of water supply with water demand of crop $i$.

Normally, the coupling degree of water supply with water demand for crops is defined as the degree of satisfaction of water supply during a certain or the whole growth period (Formula (3)). 
Its value varies from 0 to 1 , and the value is 0 when the water supply is 0 , and the value is 1 when the water supply is equal to or greater than the crop water requirement.

$$
\alpha_{i}= \begin{cases}1 & \left(P_{e_{i}}>E T_{m_{i}}\right) \\ P_{e_{i}} / E T_{m_{i}} & \left(P_{e_{i}} \leq E T_{m_{i}}\right)\end{cases}
$$

where $P_{e i}(\mathrm{~mm})$ is the water supply during a certain growth period of or during the whole growth period of crop $i, E T_{m i}(\mathrm{~mm})$ is the crop water demand during a certain growth period of or during the whole growth period of crop $i$.

$\alpha_{i}$ can be calculated by the stage (e.g., a certain portion or the whole growth period of crop $i$ ); the coupling degree of water supply with water demand during the whole growth stage $(\alpha)$ equals to the sum of the coupling degree of each stage multiplied by the weight of water requirement (Formula 4).

$$
\alpha=\sum_{i=1}^{n} \frac{E T_{m_{j}}}{E T_{m}} \alpha_{i}
$$

where $E T_{m}(\mathrm{~mm})$ is the water requirement during the whole growth period, and $E T_{m j}(\mathrm{~mm})$ is the water requirement during $j$ th growth period.

The crop water requirement can be calculated by Penman-Monteith equation [20]. The equation is given as follows:

$$
\begin{gathered}
E T=\beta E T_{0} \\
E T_{0}=\frac{0.408 \Delta\left(R_{n}-G\right)+r \frac{900}{T+273} U_{2}\left(e_{s}-e_{a}\right)}{\Delta+r\left(1+0.34 U_{2}\right)}
\end{gathered}
$$

where $E T$ is the crop water requirement in $\mathrm{mm} \cdot$ day $^{-1}, \beta$ is the crop coefficient, $E T_{0}$ is the reference crop evapotranspiration in $\mathrm{mm} \cdot \mathrm{day}^{-1}, R_{n}$ is the net radiation in $\mathrm{MJ} \cdot \mathrm{m}^{-2} \cdot$ day $^{-1}, \mathrm{G}$ is the soil heat flux in $\mathrm{MJ} \cdot \mathrm{m}^{-2}$. day ${ }^{-1}, T$ is the daily average temperature at $2-\mathrm{m}$ above the land surface in ${ }^{\circ} \mathrm{C}, U_{2}$ is the wind speed at $2-\mathrm{m}$ in $\mathrm{m} \cdot \mathrm{s}^{-1}, e_{s}$ is saturated water vapor pressure in $\mathrm{kPa}, e_{a}$ is actual water vapor pressure in $\mathrm{kPa}, \Delta$ is the slope of the saturation vapor pressure versus temperature relationship in $\mathrm{kPa} \cdot{ }^{\circ} \mathrm{C}^{-1}$, and $r$ is the psychrometric coefficient in $\mathrm{kPa} \cdot{ }^{\circ} \mathrm{C}^{-1}$.

It is assumed that the coupling degree for crop $i$ was optimal when the yield per unit area was the highest during the study period, and the crop yield loss was the difference between the highest yield and the average yield per unit area during the study period. So, the yield loss during a specific growth period of or during the whole growth period is computed as:

$$
C_{i j}=D_{i j t}-D_{i j a}
$$

where $C_{i j}$ is the yield loss of crop $i$ in $\mathrm{kg} / \mathrm{hm}^{2}$ during the $j$ or the whole growth period, $D_{i j t}$ is the highest yield per unit area of crop $i$ in $\mathrm{kg} / \mathrm{hm}^{2}$ during the $j$ or the whole growth period, $D_{i j a}$ is the average yield per unit area of crop $i$ in $\mathrm{kg} / \mathrm{hm}^{2}$ during the $j$ or the whole growth period. The yield losses of the different growth periods can be calculated by the total yield loss of the whole growth period multiplied by the time proportions of the different periods.

\subsection{Water Constraint Risk Assessment for the Adjustment and Optimization of Cropping Systems}

Water constraint risk assessment refers to the qualitative or quantitative analysis of the risk of water constraint to cropping systems. If the risk of one crop or cropping system is higher than another, it implies that the likelihood and magnitude of the loss from planting the crop or cropping system might be higher than that from planting another. Usually, the planted areas of the crop or the cropping system with relatively lower risk should be enlarged while the planted areas with relatively high risk should be reduced. 
As the cropping system consists of one crop or several crops, the water constraint risk of the cropping system is decided by the highest one of all crops' risks. For example, the water constraint risk of the double cropping system is the higher one of the water constraint risk of two crops, and so on. Based on estimated risks, the cropping systems can be adjusted and optimized.

\section{Results}

\subsection{Analysis of Crop Water Requirements}

Based on Formula (5) and the daily meteorological data in Daxing from 1980 to 2010, the average monthly water requirements of each crop were calculated (Table 2). The highest water requirement was found in rice paddies $(913.15 \mathrm{~mm})$, followed by the winter wheat-summer grain crops (summer corn, peanut, soybean), whose water requirements during the whole growth periods were around $880 \mathrm{~mm}$. Among all of the spring crops (rice, spring corn, foxtail millet, and broomcorn), the water demand of spring corn was only below the rice, and the lowest water requirement occurred in foxtail millet, followed by the broomcorn.

Table 2. The average water demand of cropping systems in Daxing during 1980-2010 (mm).

\begin{tabular}{|c|c|c|c|c|c|c|c|c|c|c|}
\hline Cropping System & March & April & May & June & July & August & September & October & November & $\begin{array}{c}\text { The Whole } \\
\text { Period }\end{array}$ \\
\hline Rice & 0.0 & 126.1 & 200.2 & 189.5 & 173.9 & 126.2 & 97.2 & 0.0 & 0.0 & 913.2 \\
\hline Foxtail millet & 0.0 & 45.8 & 77.0 & 83.7 & 101.4 & 82.0 & 0.0 & 0.0 & 0.0 & 390.0 \\
\hline Spring corn & 0.0 & 45.8 & 92.4 & 126.3 & 166.6 & 121.2 & 72.0 & 0.0 & 0.0 & 624.4 \\
\hline $\begin{array}{l}\text { Winter wheat-summer } \\
\text { peanut }\end{array}$ & 70.9 & 160.4 & 169.4 & 79.0 & 130.4 & 145.2 & 82.7 & 24.1 & 13.0 & 875.0 \\
\hline $\begin{array}{l}\text { Winter wheat-summer } \\
\text { soybean }\end{array}$ & 70.9 & 160.4 & 169.4 & 94.8 & 137.7 & 145.2 & 72.9 & 24.1 & 13.0 & 888.3 \\
\hline
\end{tabular}

\subsection{Analysis of Coupling Degree of Water Supply with Water Demand of Cropping Systems}

In Daxing, the water supply mainly depends on precipitation; so, we here considered the water supply to be equivalent to precipitation. To compare the different characteristics of the different precipitation year types, we divided all years into three precipitation year types according to the anomaly percentage (AP) of precipitation, including wet year $(\mathrm{AP}>10 \%)$, normal year $(-10 \%<=\mathrm{AP}$ $<=10 \%)$, and drought year ( $\mathrm{AP}<-10 \%$ ).

Based on monthly precipitation and water demand of cropping systems, we identified the amount of water gains and losses during the study period; i.e., the balance between the water requirement and precipitation of all cropping systems (Figure 2). The balances between precipitation and water demand from high to low were: foxtail millet $>$ broomcorn $>$ spring corn $>$ winter wheat-summer peanut $>$ winter wheat-summer soybean $>$ winter wheat-summer corn $>$ rice. The balances between the precipitation and the water requirement of rice and winter wheat-summer grain crops all presented negative, especially in drought years where more than $500 \mathrm{~mm}$ water losses occurred. There were slight water losses during the spring corn growth period in the normal years and drought years. Generally, the precipitation could meet the water demand of broomcorn and foxtail millet in all years.

Table 3 shows that, during 1980-2010, among the four spring-sown crops, the coupling degrees of precipitation with water demand of broomcorn and foxtail millet were relatively high, with the mean value of 0.80 , followed by the spring corn and least in rice paddies. The precipitation could generally meet the demand of broomcorn from June to September, while the coupling degree was relatively lower in April and May. The coupling degree of spring foxtail millet was also low in April and May (when it was sowed), and there was relatively little precipitation. However, when the rainy season came, the precipitation was enough to meet the water demand. For spring corn, the precipitation in 
July and August can generally meet the water demand in wet years and normal years, but the coupling degree was relatively low in April, May, and June because of low precipitation when supplemental irrigation was needed to help its germination. Under high water requirement, the coupling degree was always low, and irrigation was needed.

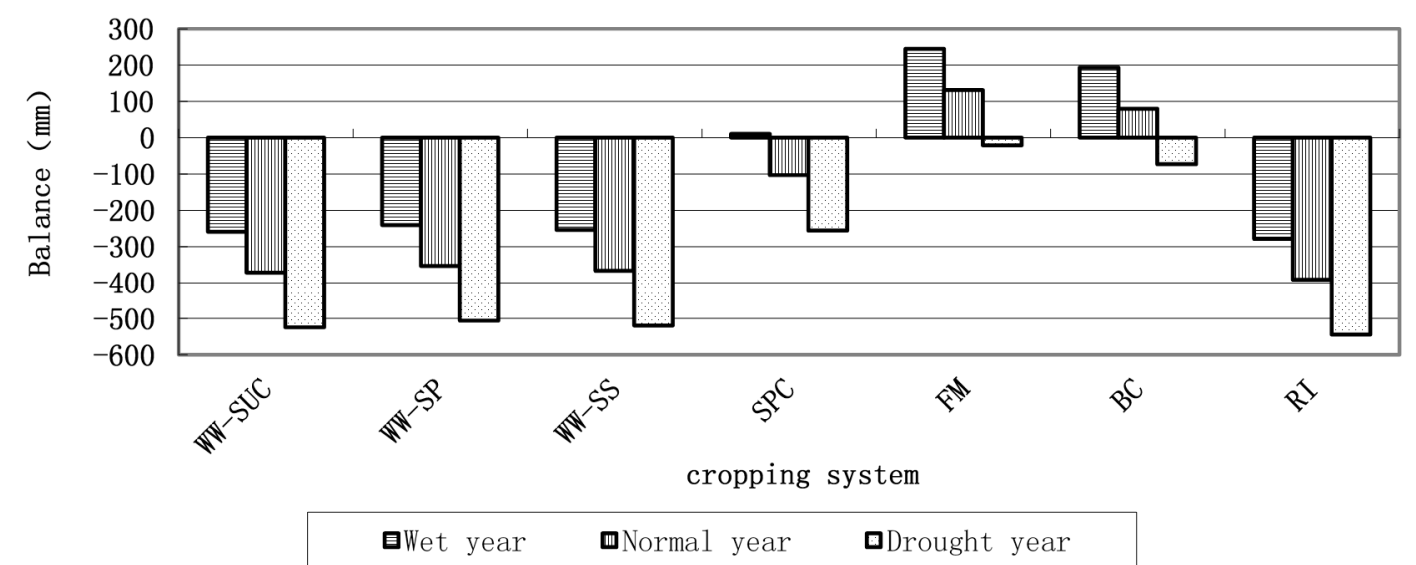

Figure 2. The balance between precipitation and water demand of cropping systems during 1980-2010. WW: winter wheat, SUC: summer corn, SP: spring peanut, SS: summer soybeans, SPC: spring corn, FM: foxtail millet, RI: rice, BC: broomcorn. The same as the following figures.

Table 3. The coupling degrees of precipitation with water demand of single cropping systems.

\begin{tabular}{cccccccccc}
\hline $\begin{array}{c}\text { Cropping } \\
\text { System }\end{array}$ & $\begin{array}{c}\text { Precipitation } \\
\text { Year Type }\end{array}$ & April & May & June & July & August & September & $\begin{array}{c}\text { Whole } \\
\text { Period }\end{array}$ & $\begin{array}{c}\text { Mean } \\
\text { Value }\end{array}$ \\
\hline \multirow{5}{*}{ Rice } & Wet year & 0.16 & 0.22 & 0.44 & 1.00 & 1.00 & 0.62 & 0.56 & \\
& Normal year & 0.28 & 0.19 & 0.4 & 0.55 & 1.00 & 0.56 & 0.47 & 0.46 \\
& Drought year & 0.16 & 0.14 & 0.28 & 0.75 & 0.57 & 0.29 & 0.36 & \\
\hline \multirow{5}{*}{ Broomcorn } & Wet year & 0.45 & 0.58 & 0.97 & 1.00 & 1.00 & 1.00 & 0.86 & \\
& Normal year & 0.76 & 0.51 & 0.88 & 0.95 & 1.00 & 1.00 & 0.85 & 0.80 \\
& Drought year & 0.43 & 0.37 & 0.62 & 1.00 & 0.88 & 0.58 & 0.69 & \\
\hline \multirow{3}{*}{ Foxtail millet } & Wet year & 0.45 & 0.58 & 1.00 & 1.00 & 1.00 & - & 0.85 & \\
& Normal year & 0.76 & 0.51 & 0.91 & 0.95 & 1.00 & - & 0.84 & 0.80 \\
& Drought year & 0.43 & 0.37 & 0.64 & 1.00 & 0.88 & - & 0.71 & \\
\hline \multirow{3}{*}{ Spring corn } & Wet year & 0.45 & 0.47 & 0.67 & 1.00 & 1.00 & 0.83 & 0.79 & \\
& Normal year & 0.76 & 0.44 & 0.6 & 0.58 & 1.00 & 0.76 & 0.68 & 0.67 \\
& Drought year & 0.43 & 0.28 & 0.42 & 0.78 & 0.6 & 0.39 & 0.53 & \\
\hline
\end{tabular}

Although the coupling degrees of precipitation with water demand of winter wheat-summer grain crops were similar (Table 4), the coupling degree of winter wheat was very low, because it grows mainly in autumn, winter, and spring when the precipitation is too little to meet its demand - especially in March and April, when the coupling degree was only around 0.1 to 0.2 and supplementary irrigation was needed. The coupling degrees of precipitation with water requirement of summer grain crops were quite high, and the precipitation could always satisfy their needs in July and August. Figure 3 shows that the coupling degrees from high to low were: broomcorn $>$ foxtail millet $>$ spring corn $>$ winter wheat-summer corn $>$ winter wheat-summer soybean, winter wheat-summer peanut $>$ rice. 
Table 4. The coupling degrees of precipitation with water demand of double cropping systems.

\begin{tabular}{cccccccccccccc}
\hline $\begin{array}{c}\text { Cropping } \\
\text { System }\end{array}$ & $\begin{array}{c}\text { Precipitation } \\
\text { Year Type }\end{array}$ & March & April & May & June & July & August September October & November $\begin{array}{c}\text { Annual } \\
\text { Values }\end{array}$ \\
\hline $\begin{array}{c}\text { Winter } \\
\text { wheat-summer }\end{array}$ & Wet year & 0.18 & 0.13 & 0.26 & 0.82 & 1.00 & 1.00 & 0.65 & 1.00 & 0.62 & 0.60 \\
corn & Normal year & 0.21 & 0.22 & 0.23 & 0.74 & 0.79 & 1.00 & 0.59 & 0.97 & 0.88 & 0.57 & 0.55 \\
& Drought year & 0.07 & 0.12 & 0.17 & 0.52 & 1.00 & 0.52 & 0.31 & 0.89 & 0.77 & 0.47 & 0.60 \\
Winter & Wet year & 0.18 & 0.13 & 0.26 & 1.00 & 1.00 & 1.00 & 0.72 & 1.00 & 0.62 & 0.60 \\
wheat-summer & Normal year & 0.21 & 0.22 & 0.23 & 0.97 & 0.74 & 1.00 & 0.66 & 0.97 & 0.88 & 0.57 & 0.53 \\
soybean & Drought year & 0.07 & 0.12 & 0.17 & 0.68 & 1.00 & 0.50 & 0.34 & 0.89 & 0.77 & 0.42 \\
\hline Winter & Wet year & 0.18 & 0.13 & 0.26 & 0.89 & 1.00 & 1.00 & 0.82 & 1.00 & 0.62 & 0.60 \\
wheat-summer & Normal year & 0.21 & 0.22 & 0.23 & 0.81 & 0.70 & 1.00 & 0.75 & 0.97 & 0.88 & 0.56 & 0.53 \\
peanut & Drought year & 0.07 & 0.12 & 0.17 & 0.56 & 0.95 & 0.50 & 0.39 & 0.89 & 0.77 & 0.42 \\
\hline
\end{tabular}

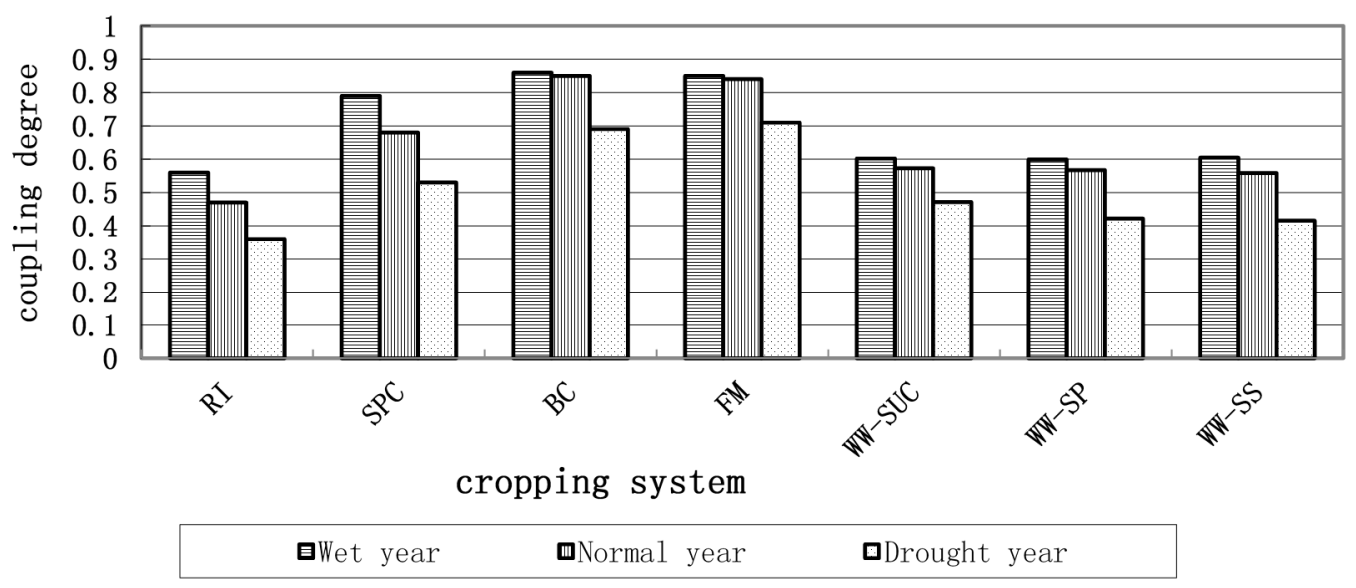

Figure 3. The average coupling degrees of precipitation with water demand of cropping systems in Daxing, Beijing during 1980-2010.

\subsection{Assessment of Water Constraint Risk and Adjustment and Optimization of Cropping Systems}

After calculations based on the Formula above, we find that the water constraint degrees were relatively lower for the crops sowed in spring or early summer. The average constraint degree of broomcorn and foxtail millet in different precipitation year types was around $20 \%$, followed by the spring corn. The highest constraint degrees were found in rice and wheat, with mean values above $50 \%$ in different precipitation year types.

According to the previous studies [21,22], we calculated the possible reduced production of winter wheat, summer corn, and rice under water constraint. By comparing with the optimal yield, the yield losses of three crops during different growth periods were calculated. Then, the water constraint risks of crops in each growth period were calculated using Formula (1). The results show that the water constraint risk of the winter wheat was the greatest, followed by the rice. The lowest water constraint risk occurred in the summer corn. For the winter wheat, the greatest water constraint risk was found in the elongation and booting stage ( $2.17 \mathrm{t} / \mathrm{ha})$, followed by the seedling and tillering period (1.22 $\mathrm{t} / \mathrm{ha})$. Similarly, rice also had a higher risk during the elongation and booting period $(0.64 \mathrm{t} / \mathrm{ha})$. For the summer corn, the results suggest a higher water constraint risk during the heading and filling periods.

For the water constraint risks of crops in the whole growth period, the results show that the water constraint risks of crops from high to low were: wheat $>$ rice $>$ broomcorn $>$ foxtail millet $>$ summer soybean $>$ summer peanut $>$ spring corn $>$ summer corn (Table 5). The winter wheat had the highest water constraint risk, followed by the rice. 
Table 5. The average water constraint risks of crops in Daxing during 1980-2010 (kg/ha).

\begin{tabular}{ccccccccc}
\hline Crop & Rice & Wheat & $\begin{array}{c}\text { Summer } \\
\text { Corn }\end{array}$ & Broomcorn & $\begin{array}{c}\text { Foxtail } \\
\text { Millet }\end{array}$ & $\begin{array}{c}\text { Summer } \\
\text { Soybean }\end{array}$ & $\begin{array}{c}\text { Summer } \\
\text { Peanut }\end{array}$ & $\begin{array}{c}\text { Spring } \\
\text { Corn }\end{array}$ \\
\hline Wet year & 270.47 & 435.59 & 1.20 & 221.20 & 217.50 & 40.07 & 8.34 & 2.29 \\
Normal year & 325.79 & 462.39 & 2.18 & 237.00 & 232.00 & 136.24 & 25.03 & 3.49 \\
Drought year & 393.40 & 469.09 & 4.36 & 489.80 & 420.50 & 296.52 & 58.40 & 5.13 \\
$\quad$ Mean & 332.33 & 455.47 & 2.68 & 329.25 & 299.82 & 164.16 & 32.03 & 3.70 \\
\hline
\end{tabular}

According to the calculations above, we got the water constraint risks of the double cropping system by selecting the greater water constraint risk of the two crops. So, we obtained the water constraint risks of each cropping system during their whole growth periods, as displayed in Figure 4 . The results suggest that the order of water constraint risks of the cropping systems in Daxing was: winter wheat-summer grain crops $>$ rice $>$ broomcorn $>$ foxtail millet $>$ spring corn. Water constraint risks of double cropping systems were higher than that of the spring-sown crops.

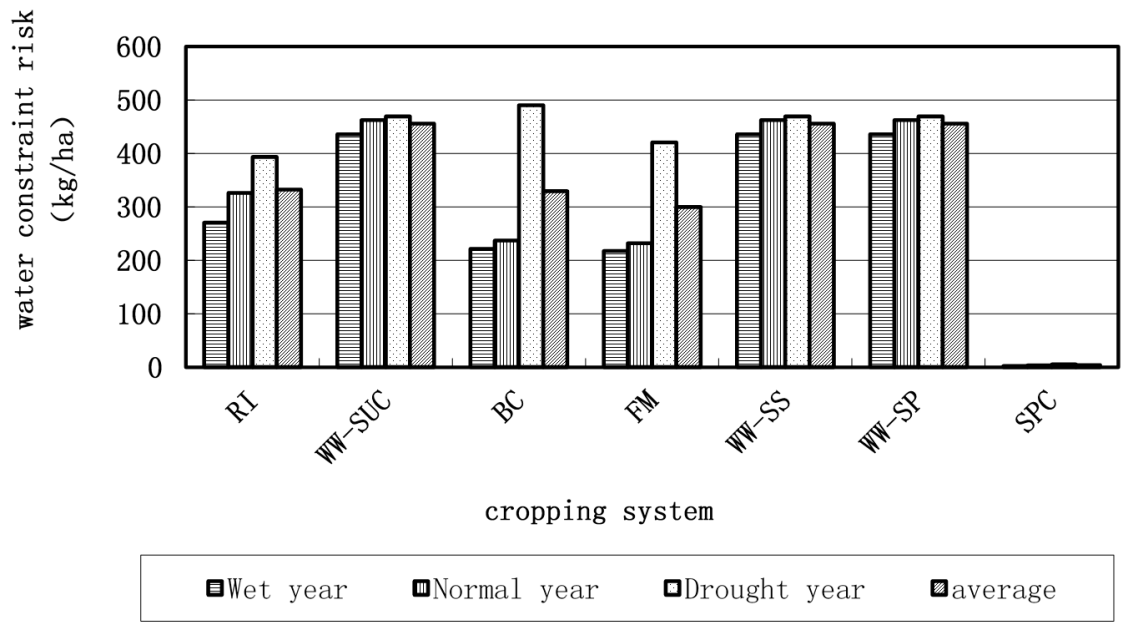

Figure 4. The average water constraint risks of each cropping system in the whole growth period during 1980-2010.

Therefore, among the three main crops, we found that water constraint risk of winter wheat was the greatest, followed by rice and summer corn. The greatest water constraint risks of winter wheat and rice occurred in elongation and booting stage, and summer corn had a higher risk during the heading and filling period.

\section{Discussion and Conclusions}

How to mitigate and adapt to potential water constraint is a key issue for ensuring food security and achieving sustainable agriculture in the context of climate change. Here, we advanced the concept of water constraint risk of cropping systems, and proposed an approach to evaluate the water constraint risks of agricultural production for the adjustment and optimization of the cropping systems. The case study in the Daxing District in Beijing, China, shows that the method of adjusting and optimizing cropping systems is practicable. The evolution process of the cropping systems in Daxing (see the section of Study area) shows that the crops and cropping systems with high water consumption were gradually replaced by those with low water consumption as the water constraint risk increased. Rice is no longer planted, and the risky double cropping systems such as winter wheat-summer corn have also been gradually transformed into single cropping with less risk (such as spring corn). Moreover, local farmers and stakeholders are discussing the possibility and feasibility of decreasing the planted area of winter wheat. Our results (as shown in Figure 4) are consistent with the actual evolution 
process of cropping systems prescribed above, indicating that the proposed approach for adjusting and optimizing cropping systems is practicable. In addition, our proposed approach can be used to compute the water constraint degrees in the different growing periods (as in Tables 3 and 4). Therefore, the critical periods affecting crop growth and development could be determined, which would be greatly helpful for the time layout of the crops. In addition, this approach is also reliable because it combines the connotation of risk with the effect of water constraint on crop yield. Based on the analyses above, we think our proposed approach can be used in other regions to adjust and optimize cropping systems under resource constraints. Considering the relatively complex computation of crop water requirement, this approach is more suitable for government decision making than for farmers.

The results of our assessment of the average risk provides a fundamental basis for the adjustment of cropping systems, although some uncertainties need to be reduced in future work. For example, in this study, we only considered precipitation in the calculation of water supply due to data availability, though irrigation also served as a water source for crops in the study area. Additionally, the runoff, infiltration, and other water consumption items were not subtracted from the precipitation, which may underestimate, to some degree, the risk of water constraint. Concerning the unit of water constraint risk, normalized values instead of absolute yield losses will be developed. In addition, the average risk was calculated based on the historical data from 1980 to 2010. For a specific year, the result might not completely accord with the actual situation due to interannual climate variability. We will improve our approach by integrating algorithms from hydrological model and finer input data sets.

Acknowledgments: This research was supported by the National Natural Science Foundation of China under Grant (No. 41271110), the National Non-profit Research Foundation for Meteorology of China under Grant (No. GYHY201506016), and the National Key Technology R\&D Program of China under Grant (No. 2015BAD06B01).

Author Contributions: Pingli An conceived and designed the study; Xilin Liu and Pingli An analyzed the data; Xuemin Li and Mengmei Song contributed the analysis of data; Pingli An and Wei Ren wrote the paper. All authors contributed to the discussions and interpretation of results.

Conflicts of Interest: The authors declare no conflict of interest.

\section{References}

1. Nafziger, E. Cropping System. Available online: http://extension.cropsciences.illinois.edu/handbook/ (accessed on 16 November 2016).

2. Tumer, N.C. Further progress in crop water relations. Adv. Agron. 1997, 58, 293-337.

3. Marvin, E.J. Water productivity: Science and practice beyond irrigation efficiency. Irrig. Sci. 2007, 25, 213-245.

4. Ericksen, P.J.; Ingram, J.S.I.; Liverman, D. Food security and global environmental change: Emerging Challenges. Environ. Sci. Policy 2009, 12, 373-377. [CrossRef]

5. De Fraiture, C.; Molden, D.; Wichelns, D. Investing in water for food, ecosystems, and livelihoods: An overview of the comprehensive assessment of water management in agriculture. Agric. Water Manag. 2010, 97, 495-501. [CrossRef]

6. De Fraiture, C.; Wichelns, D. Satisfying future water demands for agriculture. Agric. Water Manag. 2010, 97, 502-511. [CrossRef]

7. Gordon, L.J.; Finlayson, C.M.; Falkenmark, M. Managing water in agriculture for food production and other ecosystem services. Agric. Water Manag. 2010, 97, 512-519. [CrossRef]

8. Liu, Y.L.; Pan, Z.H.; Zhuang, Q.L.; Miralles, D.G.; Teuling, A.J.; Zhang, T.L.; An, P.L.; Dong, Z.Q.; Zhang, J.T.; He, D.; et al. Agriculture intensifies soil moisture decline in Northern China. Sci. Rep. 2015, 5. [CrossRef] [PubMed]

9. Liu, D.; Feng, Z.; Fang, Y. Agricultural restructuring considering crop water requirement cost in Beijing-Tianjin-Hebei region. Trans. CSAE 2007, 7, 58-63. (In Chinese with English Abstract)

10. Gao, R.; Wang, W.; Song, L. Planting Planning in Beijing Region Based on Spatial Analysis of Crop Water Requirment. South-North Water Transf. Water Sci. Technol. 2009, 4, 109-112. (In Chinese) 
11. Seckler, D.; Molden, D.; Amarasinghe, U.; De Fraiture, C. Water Issues for 2025: A Research Perspective; International Water Management Institute: Colombo, Sri Lanka, 2000.

12. Li, X. Countermeasure Study on Sustainable Exploitation of Agricultural Water Resources in Northwest China. Ph.D. Thesis, Huazhong Agricultural University, Wuhan, China, 2001. (In Chinese with English Abstract)

13. Yang, X.; Yao, X.; Pu, J. Changes of Arid Climate in Tianshui and Adjustment of Planting Structure of Summer and Autumn Crops. Adv. Clim. Chang. Res. 2009, 3, 179-184. (In Chinese with English Abstract)

14. Zhang, G.; Liu, Z.; Fei, Y. The relationship between the distribution of irrigated crops and the supply capability of regional water resources in North China Plain. Acta Geosci. Sin. 2010, 1, 17-22. (In Chinese with English Abstract)

15. Mowbray, A.H.; Blanchard, R.H. Insurance, Its Theory and Practice in the United States, 4th ed.; McGraw-Hill: New York, NY, USA, 1955.

16. Crane, F.G. Insurance Principles and Practices, 2nd ed.; Wiley: New York, NY, USA, 1984.

17. International Standards Organization (ISO). ISO Guide 73-2009; International Standards Organization: Geneva, Switzerland, 2009.

18. Luko, S.N. Risk Management Terminology. Qual. Eng. 2013, 25, 292-297. [CrossRef]

19. Intergovernmental Panel on Climate Change (IPCC). Climate Change 2014: Impacts, Adaptation and Vulnerability. Part A: Global and Sectoral Aspects. Contribution of Working Group II to the Fifth Assessment Report of the Intergovernmental Panel on Climate Change; Field, C.B., Barros, V.R., Dokken, D.J., Mach, K.J., Mastrandrea, M.D., Bilir, T.E., Chatterjee, M., Ebi, K.L., Estrada, Y.O., Genova, R.C., et al., Eds.; Cambridge University Press: Cambridge, UK, 2014.

20. Food and Agriculture Organization of the United Nations (FAO). Crop Evapotranspiration-Guidelines for Computing Crop Water Requirements_FAO Irrigation and Drainage Paper 56; FAO: Rome, Italy, 1998; pp. 89-95.

21. Wang, Y.; Wang, X.; Zhao, S. Relationship between Corn Yield and Soil Water in Different Growing Stages. Agric. Res. Arid Areas 1998, 1, 100-105. (In Chinese with English Abstract)

22. Wang, M. Effects of Drought Stress in Different Development Stages on Wheat Yield. J. Anhui Agric. Sci. 2010, 5, 600-610. (In Chinese with English Abstract)

(C) 2016 by the authors; licensee MDPI, Basel, Switzerland. This article is an open access article distributed under the terms and conditions of the Creative Commons Attribution (CC-BY) license (http://creativecommons.org/licenses/by/4.0/). 